\title{
THE MALPRACTICE OF PSYCHIATRISTS
}

\author{
Donald J. DaWIDOFF*
}

Problems relating to the legal standard of care to be imposed upon members of the medical profession have aroused increasing interest in recent years. Particularly difficult to define is the legal obligation on the part of the doctor growing out of the intimate relationship between a psychiatrist and his patient. In this article the author critically analyzes the rather sparse case law dealing with this variation of the physician-patient relation and sets down numerous guidelines in this still-developing area of the law.

$\mathrm{O}$ NE OF THE most widespread afflictions to health today is mental illness, ${ }^{1}$ and the use of psychotherapy to treat certain forms of this illness has made psychiatry a significant and growing field of medicine. Despite the increased reliance on psychiatry, however, no American appellate case has been found involving a cause of action for malpractice in the use of psychotherapy. ${ }^{2}$ This fact may be attributable in part to the skill of psychiatrists in handling the negative feelings of patients or to the natural reluctance of patients to open their psychiatric history to public scrutiny. The absence of any successful malpractice action may also be due to the lack of a firm doctrinal footing for such an action.

The little existing case law has often dealt with aspects of psychiatric practice where the risks are a predictable element of which the patient may be apprised before treatment, ${ }^{3}$ or has concerned the propriety of involuntary hospitalization with the most limited of

- B.A. 1957, Harvard University; LL.B. 1962, Yale University, Member, New York and District of Columbia Bars.

${ }^{2}$ See Osmundsen, New Unit Formed on Schizophrenia, N.Y. Times, Nov. 27, 1965 , p. 28, col. 7. "It has been estimated that one in every four hospital beds in this country is occupied by a schizophrenic." Ibid. Cf. Jaffe, Public Gives View on Mental Health, N.Y. Times, Nov. 28, 1965, p. 153, col. 1.

${ }^{2}$ See Annot., 99 A.L.R.2d 599, 619-20 (1965). See generally Bellamy, Malpractice Risks Confronting the Psychiatrist: A Nationwide Fifteen-Year Study of Appellate Court Cases, 1946 to 1961, 118 AMERICAN J. PSYchiatry 769 (1962). One case, Hammer v. Rosen, 7 App. Div. 2d 216, 181 N.Y.S.2d 805 (1959), modified, 7 N.Y.2d 376, I65 N.E.2d 756, 198 N.Y.S.2d 65 (1960), may represent a sole exception. See note 37 infra.

- For example, the occurrence of fracture in the use of shock therapy is not uncommon. See note 13 infra and accompanying text. 
doctor-patient relationships having been established. 4 Because it may be expected that the number of cases coming before the courts will increase in the future, some aspects of malpractice as they concern the psychiatrist and his patient, with special emphasis upon the psychotherapeutic relationship, will be suggested. ${ }^{5}$

\section{The psychiatrist and his patient}

The psychiatrist and his patient meet under a variety of circumstances. An adult encountering marital difficulties, experiencing protracted headaches, or having difficulty solving a family or business crisis consults a psychiatrist on his own motion. A twelve-yearold child with an intelligence quotient of one hundred and twentyfive cannot do sixth grade work and is referred by the school principal to a psychiatrist. An adolescent girl "meets" a psychiatrist on a ward of a general hospital after a quarrel with her boyfriend has led her to slash her wrists. The mother of three children awakens from weeks of psychotic withdrawal to her first recognition of the physician who has been treating her throughout that time.

The diagnosis of a psychiatrist may range from process schizophrenia to the most transient of neurotic symptoms. Treatment can be the prescription of tranquilizing drugs after a meeting on the ward of a hospital, or it can involve psychotherapeutic sessions several times a week for a number of years. ${ }^{6}$ Each constitutes a relationship where the psychiatrist is functioning as a physician treating a patient, ${ }^{7}$ and each can form the basis of an action for malpractice.

Central to psychotherapeutic treatment is the establishment of

- See, e.g., Mezullo v. Maletz, 331 Mass. 233, 235, 118 N.E.2d 356, 358 (1954); Ayers v. Russell, 50 Hun. 282, 289, 3 N.Y. Supp. 338, 341 (Sup. Ct. 1888). See also note 20 infra and accompanying text.

- Cases involving a psychotherapeutic situation include Hammer v. Rosen, 7 App. Div. 2d 216, 181 N.Y.S.2d 805 (1959), modified, 7 N.Y.2d 376, 165 N.E.2d 756, 198 N.Y.S.2d 65 (1960); Landau v. Werner (Q.B. March 7, 1961) in The Times (London), March 8, 1961, p. 5, col. 3, aff'd (C.A. Nov. 22, 1961) in The Times (London), Nov. 23, 1961, p. 5, col. 1. Cf. Bellandi v. Park Sanitarium Ass'n, 214 Cal. 472, 6 P.2d 508 (1931); Rosenfeld v. Coleman, 19 Pa. D. \& C.2d 635, 35 North. Co. R. 206 (C.P. Northampton County Ct. 1959).

'See, e.g., Hammer v. Rosen, 7 App. Div. 2d 216, 217, 181 N.Y.S.2d 805, 806 (1959) (dissenting opinion), modified, 7 N.Y.2d 376, 165 N.E.2d 756, 198 N.Y.S.2d 65 (1960), where psychotherapeutic treatment continued for over seven years. See also Barten, "The 15-minute Hour": Brief Therapy in a Military Setting, 122 AMERICAN J. PsXCHLTRY 565 (1965).

'See Heller, Some Comments to Lawyers on the Practice of Psychiatry, 30 TEMP. L.Q. 401, 404-05 (1957). 
a relationship with the psychiatrist to which the patient can bring past experiences and emotions, and in which he can establish the model for a new method of dealing with his environment. ${ }^{8}$ Through the establishment of a transference with the psychiatrist, ${ }^{9}$ the patient reacts towards him with the emotional responses he had learned and used with his parents and siblings, thus experiencing again the emotions of the past. Through such a reliving, and the interpretation of the experience, the patient learns to understand his reactive patterns and through them to grow to new and more mature behavior. The center of the growth is often an identification with the therapist, where the patient sees in the therapist the image of the healthy person, and comes to make healthy patterns of response his own. ${ }^{10}$

\section{Shock therapy cases}

Electro and insulin shock therapy are ways of building up the patient's "defenses and controls and self-confidence" in the case of the former, and of relieving "basic anxiety" and "disturbance of the mood" in the case of the latter. ${ }^{11}$ They accomplish with a jolt what the psychotherapies achieve through directed conversation.

The cases, for the most part, seek damages for fractures resulting from the negligent application of the therapies. ${ }^{12}$ Fracture is a

\footnotetext{
${ }^{8}$ See Burnham, Separation Anxiety, 13 Archives General Psychiatry 346 (1965). "The therapist's own behavior also constitutes an important model for the patient who will introject qualities of solid reliability as he perceives them in the doctor. ... The model function of the therapist who demonstrates how he handles conflicts, uncertainties, and troublesome affects has been emphasized by various authors in. cluding Hoedemaker and Szasz." Id. at 357.

See Rosenfeld v. Coleman, 19 Pa. D. \& C.2d 635, 639, 35 North. Co. R. 206, 209 (C.P. Northampton County Ct. 1959); Landau v. Werner (Q.B. March 7, 1961) in The Times (London), March 8, 1961, p. 5, col. 3, aff'd (C.A. Nov. 22, 1961) in The Times (London), Nov. 23, 1961, p. 5, col. 1; Heller, supra note 7, at 406.

${ }^{10}$ See Burnham, supra note 8 , at 357.

${ }^{11}$ Mitchell v. Robinson, 334 S.W.2d 11, 12 (Mo. 1960). See Mitchell v. Robinson, 360 S.W.2d 673 (Mo. 1962). See also Horwitz, Insulin Shock Therapy in 2 AMERCAN HandBook of Psychiatry 1485 (Arieti ed. 1959) where the author observes that shock therapy has been "considered the most accepted somatic treatment for schizophrenia," ibid., and has been employed in treating paranoia, id. at 1496, but has decreased in use because of the dangers involved and because of the advent of tranquilizing drugs, id. at 1485-86.

Shock therapy may also be used as a means of combatting depression. See Kalinowsky, Convulsive Shock Treatment in 2 AMERICAN HANDBOoK of Psychiatry 1499, 1510 (Arieti ed. 1959).

${ }^{12}$ See, e.g., Johnston v. Rodis, 251 F.2d 917 (D.C. Cir. 1958); Mitchell v. Robinson, 360 S.W.2d 673 (Mo. 1962) (failure to warn of hazards); Bolan v. Friern Hosp. Comm., [1957] 2 A11 E. R. 118 (Q.B.).
} 
knorwn incident of electro and insulin shock therapy. Either through passage of an electric current through the brain, or through the injection of insulin, a convulsion occurs which causes fractures in a modest but measurable percentage of the cases. ${ }^{13}$ The risks of physical injury incident to shock therapy exist without regard to the degree of care exercised by the physician or those to whom its administration has been delegated. ${ }^{14}$ The threat of fracture, however, would appear to be compensated for by the possibility of the remedial effects, and it is not surprising that the courts have refused to hold doctors absolutely liable. ${ }^{15}$

So long as the patient is fully informed beforehand of the injurious side effects, it may be convincingly argued that he has consented to the risks involved. To assure the maximum efficacy of this defense, the doctor should explain the dangers to the patient or to someone acting in his behalf and procure a signed consent form in which the hazards are simply and clearly set forth. ${ }^{16}$ Aside from those instances involving the negligent administration of the therapy, what victories plaintiffs have achieved have been in cases where these procedures were not followed, and the

${ }^{13}$ See Farber v. Olkon, 40 Cal. 2d 503, 524 P.2d 520 (1953). Quoting the "undisputed testimony" of a medical expert, the court observed: "[T] he overall incidence of fractures in shock treatment varies anywhere from perhaps one-half to about three and a half per cent. If one considers fractures of the spine . . the incidence is between 10 and 40 per cent." Id. at 511, 254 P.2d at 525. See also Mitchell v. Robinson, 334 S.W.2d 11, 13-14 (Mo. 1960) (mentioning expert testimony of fractures in 18,19 , and 25 per cent of the cases involved in three studies); Stone v. Proctor, 259 N.C. $633,637,131$ S.E.2d 297, 300 (1963) (fractures in 15 to 30 per cent of the cases); Quinley v. Cocke, 183 Tenn. 428, 439, 192 S.W.2d 992, 997 (1946).

Another injurious side effect of shock therapy may be mental confusion or memory impairment. See Zamora and Kaelbling, Memory and Electroconvulsive Therapy, 122 American J. Psychiatry 546, 552-53 (1965).

14 E.g., Farber v. Olkon, supra note 13, at 511, 254 P.2d at 524-25; Quinley v. Cocke, supra note 13 , at 439,192 S.W.2d at 997 .

${ }^{20}$ In Quinley 7 . Cocke, the court observed that if liability were to be found upon mere proof of the injury, "the physician and surgeon would always be in fear of the result of a scientific treatment knowing that he might have to defend his professional reputation in open court." 183 Tenn. at 440, 192 S.W.2d at 997. Cf. Ewing v. Goode, 78 Fed. 442, 443 (C.C.S.D. Ohio 1897) (Taft, J.). See generally LindMan \& McIntyre, The Mentally Disabled and the Law 149-50 (1961); Note, 77 Harv. L. Rev. 393 (1963).

${ }^{10}$ See Lester v. Aetna Cas. \& Sur. Co., 240 F.2d 676, 679 (5th Cir. 1957); Woods v. Brumlop, 71 N. Mex. 221, 227, 377 P.2d 520, 524-25 (1962); Shartel \& Plant, The Law of Medical Practice 12-13 (1959); Kelly, The Physician, the Patient, \& the Consent, 8 KAN. L. REv. 405, 424-26 (1960).

For an example of such a form suggested by two physicians, one of whom had been sued for malpractice, see Rodis \& Groh, One Aspect of the Medicolegal Implications of Shock Theory, 51 SoutherN MEDICAL J. 219, 220 (1958). 
physicians either failed to explain the risks fully, ${ }^{17}$ or did not allow the patient the choice of taking or declining the therapy. ${ }^{18}$

Because the immunity afforded by a valid consent form extends only to the inherent risks of careful treatment, the patient may succeed if he can prove that the injury was caused by actual negligence and did not result from the assumed risks. Confronted with signed consent forms, patients have sometimes contended that the existence of fracture, and nothing more, denotes such negligence. This application of res ipsa loquitur has been uniformly denied.10

\section{The wrongful commitment cases}

Attempts by patients to hold psychiatrists liable in damages for wrongful commitment to mental hospitals have been hampered by conceptual difficulties. Despite mistakes in diagnosis, the cases have found no duty of care on the part of the examining and certifying psychiatrists; thus they stop short of the first barrier in the course of a malpractice action. ${ }^{20}$ Since the question involved is neither the nature of the treatment given nor the mode of therapy recommended, but instead simply whether treatment at a hospital should be compelled, the commitment cases contribute very little to an understanding of the legal limits of psychiatric practice.

Toward a usable concept of psychotherapeutic malpractice: duty of care and skill

The liability of the psychiatrist to his patient is for the breach of a duty to the patient to bring to their relationship the skill and

${ }^{17}$ E.g., Mitchell v. Robinson, 360 S.W.2d 673 (Mo. 1962); Woods v. Brumlop, 71 N. Mex. 221, 377 P.2d 520 (1962).

${ }^{18}$ Johnston v. Rodis, 251 F.2d 917 (D.C. Cir. 1958).

${ }^{20}$ E.g., Johinston v. Rodis, 151 F. Supp. 345, 347 (D.D.C. 1957), rev'd on other grounds, 251 F.2d 917 (D.C. Cir. 1958); Farber v. Olkon, 40 Cal. 2d 503, 510, 254 P.2d 520, 525 (1953); Quinley v. Cocke, 183 Tenn. 428, 440.41, 192 S.W.2d 992, 996.97 (1946).

${ }_{20}^{\circ}$ The conceptual difficulties encountered by one who attempts to bring an action against a certifying physician for wrongful commitment are inherent in the statutes which provide for precommitment examinations by doctors. The courts generally conclude that the psychiatrist is acting as a court witness and because the examination is statutorily commanded, the doctor-patient relationship does not arise. Consequently there is a complete immunity. E.g., Bartlett v. Weimer, 268 F.2d 860 (7th Cir. 1959); Mezullo v. Maletz, 331 Mass. 233, 118 N.E.2d 356 (1954); Dunbar v. Greenlaw, 152 Me. 270, 128 A.2d 218 (1956); Fowle v. Fowle, 255 N.C. 720, 122 S.E.2d 722 (196I). Contra, Kleber v. Stevens, 39 Misc. 2d 712, 241 N.Y.S.2d 497 (Sup. Ct. 1963), aff'd 20 App. Div. 2d 896, 249 N.Y.S.2d 668 (1964); Ayers v. Russell, 50 Hun. 282, 3 N.Y. Supp. 338 (Sup. Ct. 1888). 
the care of a professionally qualified psychiatrist practicing in that community. ${ }^{21}$ There need be no express undertaking on the part of the psychiatrist that he will so conduct himself, for it is his profession itself which implies the attributes of his practice..$^{22}$ The concept of skill is one of technical proficiency: knowledge of and the ability to apply the medically appropriate therapy. Care, on the other hand, imports a mode of execution, the guidance which the will gives to skill.

Courts sometimes characterize the quantum of care required as "ordinary," "extraordinary," "the highest degree," or by some other such conceptual quantification. ${ }^{23}$ The measure of care which the law exacts in a particular case may depend on various factors incident to the treatment. One court has made it a function of the mystery of the illness. ${ }^{24}$ Another has made it depend upon the gravity of the consequences of error. ${ }^{25}$ It may also be a function of the

${ }^{21}$ Johnston v. Rodis, 151 F. Supp. 345, 346 (D.D.C. 1957), rev'd on other grounds, 251 F.2d 917 (D.C. Cir. 1958) (shock therapy). Accord, Farber v. Olkon, 40 Cal. 2d $503,511,254$ P.2d 520, 525 (1953) (shock therapy); Ayers v. Russell, supra note 20, at 389, 3 N.Y. Supp. at 341 (wrongful commitment); Landau v. Werner (Q.B. March 7, 1961 ) in The Times (London), March 8, 1961, p. 5, col. 3, aff'd (C.A. Nov. 22, 1961) in The Times (London), Nov. 23, 1961, p. 5, col. 1 (psychotherapy). See McCoid, The Care Required of Medical Practitioners, 12 VAND. L. REv. 549, 559 (1959). See generally Prosser, TORTs $\$ 32$, at. $164-68$ (3d ed. 1964).

22 Ayers v. Russell, 50 Hun. 282, 289, 3 N.Y. Supp. 338, 341 (Sup. Ct. 1888). Accord, Worster v. Caylor, 231 Ind. 625, 110 N.E.2d 337 (1953) (surgeon); Riggs v. Christie, 342 Mass. 402, 405-06, 173 N.E.2d 610, 613 (1961) (general practitioner); Kennedy v. Parrott, 243 N.C. 355, 360, 90 S.E.2d 754, 756 (1956) (surgeon). See also 2 KENT, ConMENTARIES *572. "So, if a surgeon should undertake gratis to attend a wounded person, and should treat him improperly, he would be liable for improper treatment, because his profession implied skill in surgery." Ibid.; Cline, Professional Liability, 35 NEB. L. REv. 547 (1956).

The duty of care may also arise when the physician, without agreement, actually undertakes to care for the plaintiff. See McCoid, supra note 21, at 555 .

${ }^{23}$ E.g., Ayers v. Russell, supra note 22, at 289, 3 N.Y. Supp. at 341 (ordinary care); McCandless v. McWha, 22 Pa. 261, 268 (1863) (reasonable diligence); Wood v. Clapp, 36 Tenn. 26, 28 (1856) ("reasonable" degree of skill and science as opposed to "highest" degree); Landau v. Werner (Q.B. March 7, 1961) in The Times (London), March 8, 1961, p. 5, col. 3, aff'd (C.A. Nov. 22, 1961) in The Times (London), Nov. 23, 1961, p. 5, col. 1 ("very greatest care").

s' Landau v. Werner, supra note 23. "A psychiatrist had explosive forces under his control and if they were released the consequences might be disastrous. He must exercise the very greatest care in dealing with the dark secrets of the human mind." Ibid. Compare Williams v. LeBar, 141 Pa. 149, 21 Atl. 525 (1891) (per curiam). "The most the case discloses is an error of judgment, to which the most careful and skillful physician is liable in a mysterious disease like insanity." Ibid. The increase in severity in the period between Williams and Landau, arrived at while retaining the rhetoric of magic, suggests that courts will require more care of psychiatrists as the nature of the mystery of mental illness is revealed.

${ }^{35}$ Pennell v. Cummings, 75 Me. 163 (1883). "Apart from any statutory require- 
tractability of the forces being controlled: their danger, ${ }^{26}$ the skill necessary to control them ${ }^{27}$ or the interest at stake. ${ }^{28}$ Such a scaling of duty is analogous to the variations in the standards of care imposed upon bailees having different degrees of interest in the bailment. $^{29}$

Beneath the words of "skill" and "care" may be a fiduciary

ment, the law would undoubtedly hold the defendants in such a case [erroncous certificate of insanity] to the usual professional liability for due care and skill, and when the serious consequences that may fiow from reliance upon such a certificate by the municipal officers [are considered], the imprisonment of a sane person in an insane asylum, perhaps for a long time, the standard of care required and of professional learning and ability to deal with such a subject would certainly be an exacting one." Id. at 168. Cf. Mitchell v. Robinson, 334 S.W.2d 11, 19 (Mo. 1960).

${ }^{20}$ Landau v. Werner (Q.B. March 7, 1961) in The Times (London), March 8, 1961, p. 5, col. 3, aff'd (C.A. Nov. 22, 1961) in The Times (London), Nov. 23, 1961, p. 5, col. 1. As the court put it, "if mistakes were made in psychotherapy, psychoanalysis, or other forms of psychological therapy which employed transference, the consequences might be disastrous and indeed irrevocable." Ibid. A hint of the concept of dangerous instrumentality lurks behind the rule in Landau as it does behind the absoluteness of the liability in Hammer v. Rosen, 7 N.Y.2d 376, 165 N.E.2d 756, 198 N.Y.S.2d 65 (1960). That the dangerous instrumentality rule rather than the niceties 'of the law of assault will play a part in the application of the Hammer case is suggested by Sawyer v. Jewish Chronic Disease Hosp., 234 N.Y.S.2d 372, 374 (Sup. Ct. 1962). The concept of dangerous instrumentality contributes to many applications of res ipsa loquitur. Id. at 374 .

${ }^{27} \mathrm{Cf}$. Connor v. Winton, 8 Ind. 315 (1856) (malpractice of a veterinary surgeon). "The authorities are also abundant to show that, in proportion to the value of the article to be kept, or the delicacy of the operation to be performed, will the act assume character. What would be simply negligence as to one thing would be gross negligence as to another." Id. at 319. Even though it is possible that the solution to the problem in Connor is whether the procedure was medically dictated by the veterinary community, the court's use of the analogy of the bailment is interesting. The similarity in derivation of standard of care and origin of duty in the law of bailment with medical malpractice is especially apparent in a case which, by dealing with medical care of a chattel, stands in the gap between the law of bailment and that of physician and patient. Cases often cross-fertilize the two bodies of law and see the relationships in tandem.

It is suggested that the binding thread is the concept of trust arising out of a degree of control of and responsibility for someone else, or something that belongs to someone else. See note 29 infra and accompanying text. See also Schouler, BAILMENTS $\$ 2$ (1897).

${ }^{28}$ Cf. McCandless v. McWha, $22 \mathrm{~Pa} .261,268-69$ (1853) (surgeon). "The principle is contained in the pithy saying of Fitzherbert that 'it is the duty of every artificer to exercise his skill rightly, and truly, as he ought.' This is peculiarly the duty of professional practitioners, to whom the highest interests of man are often necessarily intrusted." Id. at 269.

${ }^{20}$ See, e.g., J. W. Mays, Inc. v. Hertz Corp., 15 App. Div. 2d 105, 107, 221 N.Y.S.2d 766, 768-69 (1961) (dicta) (liability only for gross negligence in gratuitous bailment); Hobbie v. Ryan, 130 Misc. 221, 223 N.Y. Supp. 654 (Sup. Ct. 1927) (liability for even slight negligence if bailment for bailee's benefit); Ciofalo v. Vic Tanney Gyms, Inc., 10 N.Y.2d 294 (1961) (dicta) (ordinary care required where bailment benefits bailor and bailee). See generally SaINer, Substantive Law of New York 29-34 (17th ed. 1964). 
matrix which governs the relationship of the psychiatrist to his patient. ${ }^{30}$ For the legal trustee,

one of the most fundamental duties ... is that he must display throughout the administration of the trust complete loyalty to the interests of the cestui que trust, and must exclude all selfish interests . . . . 31

So likewise may we ask the psychiatrist to fulfill a fiduciary duty to his patient. ${ }^{32}$ He should be expected to pursue the psychiatric or emotional well-being of the patient rather than his own emotional demands or financial objectives when these interests are in conflict. ${ }^{33}$ Then, as this fiduciary concept is applied to a given case, the consequences of the task, the risks of failure, and the amount of skill necessary to minimize the dangers will determine the demands of the relationship.

Psychotherapy gives to the concept of trusteeship twin layers of

\footnotetext{
${ }^{30}$ See note 28 supra.

31 BOGERT, TRUSTS \& TRUSTEES $\$ 543$, at 473-74 (2d ed. 1960); to the same effect is 2 Scorr TRUSTs $\S 170$, at 1193 (2d ed. 1956). According to Blackstone, it was for a breach of such trust that the action of malpractice would lie: "Injuries affecting a man's health are where, by any unwholesome practices of another, a man sustains any apparent damage in his vigour or constitution. As . . by the neglect or unskilful management of his physician, surgcon, or apothecary. For it bath beer solemnly resolved that mala praxis is a great misdemeanor and offense at common law, whether it be for curiosity and experiment, or by neglect; because it breaks the trust which the party had placed in his physician, and tends to the patient's destruction." 3 Blackstone, Commentaries 122 (Sharswood ed. 1868). Doctrinally, Blackstone saw the action as arising for the breach of a contract implied in law. Ibid.

${ }^{32}$ The duty of disclosure has been bottomed upon the trust and confidence marking the physician-patient relationsbip. See Colvin v. Warren, 44 Ga. App. 825, 163 S.E. 268, 269 (1932). It is within such a framework that we may understand cases which depart from a strict rule requiring full disclosure to the patient of the risks of treatment under all circumstances. See, e.g., Woods v. Brumlop, 71 N. Mex. 211, 227, 377 P.2d 520, 524 (1962); Bolam v. Friern Hosp. Comm., [1957] 2 All E.R. 118 (Q.B.).

The cases of electroshock therapy which result in fracture where negligence is alleged in failing to warn of the risks raise this issue nicely. They recognize the duty of the psychiatrist to obtain consent to a physical invasion of the patient's person as an operative procedure. The patient's interest in self-determination of the physical disposition of his person is paramount. In these cases, however, the obligation of the physician involves the further duty to prefer the patient's interest in being shielded from the incidents of shock and fear (leading him, in the difficult case, to withdraw consent) which accompany his being told of the risks. The psychiatrist may find it therapeutically necessary to subordinate his own interest in procuring an "iron-clad" consent form. Therefore, some courts have liberalized the rule necessitating disclosure when there is danger of unduly alarming the patient. See Woods v. Brumlop, supra at 228, 377 P.2d at 525 (dictum); Hunt v. Bradshaw, 242 N.C. $517,523,88$ S.E.2d 762,766 (1955).

${ }^{33}$ See note 28 supra.
} 
meaning, for the essence of much psychotherapy is the contribution of trust in the external world and ultimately in the self, modelled upon the trusting relationship established during therapy. ${ }^{34}$ This gives to the action of psychiatric malpractice a double sounding of breach of trust, and casts the larger ambit of a psychotherapeutic malpractice action in some detail.

The requirement of separation of interest which is demanded of a legal trustee, however, encounters some special difficulty when imposed upon the psychiatrist. Specifically, there is professional medical opinion to the effect that, in the transference relationship, it is

\footnotetext{
st See, e.g., Heller, supra note 7. "Patients will be helped only if they can form a trusting relationship with the psychiatrist. Psychotherapy becomes otherwisc an ineffective and intellectual exercise. Problems in malpractice involve either a breach of this relationship by the doctor or an unusually faulty approach to the patient's problems." $I d$. at 406. "[The patient] is expected to bring up all manner of socially unacceptable instincts and urges, immature wishes, perverse sexual thoughts -in short, the unspeakable, the unthinkable, the repressed. To speak of such things to another human requires an atmosphere of unusual trust, confidence and tolerance." $I d$. at 405 .

See also Buruham, supra note 8. "A. major goal, especially in the early stage of psychotherapy, is to build a relationship in which the patient comes to trust the doctor as a reliable object." Id. at 356. "The therapist's model function is salient in his manner of handhing major separation from the patient. In general, a matter. of-fact calm trust in the patient's internal resources is helpful, in contrast to an attitude which conveys an uncomfortable, guilt-tinged, fearful concern that the patient may be adversely affected by the separation." Id. at 357. See note 8 supra.

This then is the application of the therapeutic concept of trust to a specific category of illness. As a characterization of the relationship of psychotherapist and patient, and of the specific impartment of a therapy, the concept of trust shares viability at different levels. But basic to all is the total concept of trust in human development of which these are but the specific reflection.

See generally ERIKson, I Psycholocical Issues 50-63 (1959). "For the first component of the healthy personality I nominate a sense of basic trust, which I think is an attitude toward oneself and the world derived from the experiences of the first year of life. By 'trust' I mean what is commonly implied in a reasonable trustfulness as far as others are concerned and a simple sense of trustworthiness as far as oneself is concerned. When I say 'basic,' I mean that neither this component nor any of those that follow are, either in childhood or in adulthood, especially conscious. In fact, all of these criteria, when developed in childhood and when integrated in adulthood, blend into the total personality. Their crisis in childhood, however, and their impairment in adulthood are clearly circumscribed." Id. at 55-56. "What wo call 'trust' coincides with what Therese Benedek has called 'confidence.' If I prefer the word 'trust,' it is because there is more naivete and more mutuality in it ....." Id. at 61 .

"At any rate, the psychiatrists, obstetricians, pediatricians, and anthropologists, to whom I feel closest, today would agree that the firm establishment of enduring pat. terns for the balance of the basic trust over basic mistrust is the first task of the budding personality and therefore first of all a task for maternal care .... Mothers create a sense of trust in their children by that kind of administration which in its quality combines sensitive care of the baby's individual needs and a firm sense of personal trustworthiness within the trusted framework of their community's life style." Id. at 63 .
} 
not possible clearly to separate social and professional conduct. ${ }^{35}$ Yet, the few cases involving psychotherapy have vaguely defined a perimeter both physical and emotional beyond which the psychiatrist is not privileged to travel. In Landau v. Werner ${ }^{36}$ a psychiatrist embarked upon a series of social visits with a patient who had "fallen in love" with him. In Hammer $v$. Rosen ${ }^{37}$ a psychiatrist

${ }^{35}$ See Landau v. Werner (Q.B. March 7, 1961) in The Times (Loudon), March 8, 1961, p. 5, col. 3, aff'd (C.A. Nov. 22, 1961) in The Times (London), Nov. 23, 1961, p. 5, col. 1 .

${ }^{3}$ Supra note 35 . The plaintiff had been referred to the defendant, a psychiatrist, in a highly nervous and emotional condition in March of 1949. He treated her by "transference," in which past emotion is reactivated and attached to the psychiatrist, causing the patient to feel towards him hopes, desires and fears of the past. By May 28, 1949, after twenty-four consultations, plaintiff had become emotionally aroused by the treatment, and sexually aroused by the intimate conversations with the defendant. When she discussed with defendaut her feelings towards him, and the consequent shame and bafflement at their development, defendant advised her to continue with the treatment, and told her that her feelings of love and bondage would cease. Having reached the stage where plaintiff was very much in love with defendant, but "so much better in health," the two came almost to the parting of the ways. In August of 1949, however, thinking plaintiff not wholly cured, and fearing a relapse to her previous anxiety state were she to be removed from his influence, defendant decided not to end their association. He began instead a series of social visits with plaintiff, all outside his consulting room where the treatment had so far taken place. They rode in taxicabs together, visited restaurants, talked of a holiday together and once visited plaintiff's bed sitting room. No improper advances on defendant's part, however, took place. Nevertheless, plaintiff failed fully to recover and, as the probable result of the further visits, experienced a decline. After attempting to terminate the relationship, defendant resumed the treatment in March of 1950, about a year after it had first begun. The electro shock therapy which he instituted did not change matters. In April of 1951 plaintiff attempted suicide. One of the other physicians whom she later saw returned her to defendant for a final attempt to resolve the transference, which effort failed.

The Court of Appeal affirmed the Queen's Bench verdict for plaintiff, holding that unrefuted proof of medical condemnation of the introduction of social visits into the course of treatment by a psychiatrist of a patient who is aroused towards him by transference and which are the probable cause for a serious decline in condition from an improved level will justify a judgment in negligence.

${ }^{37} 7$ N.Y.2d 376, 165 N.E.2d 756, 198 N.Y.S.2d 65 (1960). Parents of plaintiff, a diagnosed schizophrenic, solicited the care of defendant after plaintiff had undergone extended psychiatric care including over one hundred fifty electric shock treatments. Employing what was apparently a psychoanalytic therapy, defendant effected some initial improvement in the patient's condition. His behavior, however, allegedly included bruising of the plaintiff with slaps and beatings. Defendant did not attempt to show that the alleged assaults were part of the treatment, but rather, he denied that they were inflicted.

Over the course of seven years of treatment, moreover, the initial improvement did not prove of permanent duration, a phenomenon of "complex causation." The Court of Appeals held inter alia that it was error for the trial court to have dismissed a cause of action for malpractice, and it therefore modified the affirmance in the Appellate Division. It held in substance that expert testimony to the fact of malpractice was unnecessary where "the very nature of the acts complained of bespeaks malpractice" and therefore that the testimony of three witnesses to alleged assaults made out a prima facie case. 7 N.Y.2d at 380,165 N.E.2d at 757, 198 N.Y.S.2d at 67. 
slapped and bruised his patient on several occasions in the course of analytic treatment. Malpractice was established in each case.

Are we to infer from Landau $v$. Werner a prohibition against any encounter between a psychiatrist and patient outside the psychiatrist's office? Does Hammer $v$. Rosen mean that a psychiatrist is not privileged to put his arm around a female patient who is crying at the end of her hour and kiss her forehead? Does a psychiatrist discuss with a patient his imminent vacation at his peril?

Neither of the cases necessarily forecloses such behavior. Landau $v$. Werner finds no legitimate interest of the patient served by the social visits. The interest of the girl was instead to have the relationship terminated. ${ }^{38}$ Similarly if the clasp and the kiss are efforts to comfort or otherwise treat the patient rather than the first steps to seduction, Landau v. Werner would not appear to reach them. Likewise Hammer v. Rosen, dealing as it does with violent physical invasion, seemingly incorporates the law of assault and battery and would reach neither the privileged touching which can be involved in steadying or comforting hand-holding nor, perhaps-although the court did not reach the question-in such slaps as may be professionally countenanced. Discussion of a therapist's imminent vacation and of his need to miss a therapeutic session may be an important method of alleviating his patient's anxiety, ${ }^{30}$ and as such, would be permitted under Landau v. Werner. In a similar vein, doctor and patient may, in fact, encounter each other socially under circumstances where the worst thing a doctor could do, in therapeutic terms, might be to ignore or slight his patient. And planning a vacation at the same time as, or even at the same beach as the therapist has chosen, may under certain circumstances consti-

Such testimony likewise constituted sufficient proof of injury. The court stated that damages iu malpractice are for personal injuries including the pain and suffering naturally flowing from the tortious act. Furthermore, a jury would be warranted in finding that defendant's acts had caused the plaintiff pain and suffering. 7 N.Y.2d at 380,165 N.E.2d at 758,198 N.Y.S.2d at 68.

${ }^{38}$ See note 59 infra and accompanying text.

as See Burnham, supra note 8. "Sometimes a patient may openly and unabashedly voice his wish for an inseparable relationship, for instance in sucb direct requests as 'Take me home with you,' or 'Let me go with you on your vacation.'" Id. at 352. Or, taking another example, "In another therapy hour the therapist informed him that he would be unable to keep their appointment. . . . [T] The patient expressed first fear that others might harm him during the therapist's absence, and then anger at the therapist's 'untrustworthiness and stupidity'; then he switched to avowing friendly feelings and esteem for the therapist, in addition to concern that he might harm the doctor." Ibid. 
tute an important therapeutic step in the identification and separation process.

Like the courts, the psychiatrists must depend upon the specific facts of the therapeutic situation. Professional doctrine becomes his principal guide in discovering the patient's interest. ${ }^{40}$ The psychiatrist may rest with a therapeutic act which is countenanced by the psychiatric profession. He need not pursue a course about which there is unanimity, so long as the minority viewpoint is legitimately recognized. ${ }^{41}$

Nevertheless, in the psychotherapies, where decisions are numerous, minute, and critical, ${ }^{42}$ and where "standard procedures" may be significantly, if covertly, eschewed so that the very concept of a community of practice is shaken, ${ }^{43}$ there must be more specific gnidelines for the doctor. For example, the psychiatrist must not

\footnotetext{
10 See note 21 supra and accompanying text; see also Prosser, TorTs $\S 32$, at 166-67 (3d ed. 1964).

${ }^{42}$ See Landau v. Werner (C.A. Nov. 22, 1961) in The Times (London), Nov. 23, 1961 , p. 5, col. 1. The justice advised that courts should be chary of finding a physician negligent merely because his treatment was unsuccessful or contrary to what even a large majority of medical opinion would recommend. Ibid. See McCoid, supra note 21, at 565. "Even where there is an established mode of treatment, the physician may be permitted to innovate somewhat if he can establish that in his best judgment this was for the benefit of the patient and where the established modes have proved unsuccessful." Id. at 589. See also Prosser, op. cit. supra note 40, $\S 32$ at 166; Note, 40 CAlIF. L. REv. 159 (1959).

The issue of whether the treatment given in the Hammer case was justifiable innovation or proscribed experiment was not explicitly placed before the court, possibly to avoid the effect upon the jury of an admission of non-defensive beatings. The tactic of denying that the course of conduct was undertaken as treatment appears to have been adopted without quenching all of the brush fires. Thus, defendant's alleged exclusion of the plaintiff's nurse from his consultation room might be causally linked to the intentional application of the beatings. Furthermore, "Mrs. Hammer also testified to conversations with the defendant wherein he stated that the assaults complained of were part of the treatment." 7 App. Div. 2d at 218, 181 N.Y.S.2d at 807 .

'2 See Fisch, Resistance to Change in the Psychiatric Community, 13 Ararrves General Psychitrey 359 (1965). "Conversations are continually being steered by the therapist not only in obvious ways, such as questions, but often by such subtle clues as variations in attention, manifestations of tension such as changes in breathing, tonal emphases, and even the display of books which indicate-the therapist's areas of interest." Id. at $\mathbf{3 6 0}$. See also Burnham, supra note 8 , at $\mathbf{3 5 2}$. Compare Landau v. Werner (Q.B. March 7, 1961) in The Times (London), March 8, 1961, p. 5, col. 3: "His Lordship thought that this lady might have read into small and innocent gestures a meaning which they did not in fact possess as a result, perhaps, of the transference."

s See Fisch, supra note 42. "That conventional clinicians depart from 'proper' technique is most usually revealed in small 'trusted' groups, and as asides, rarely in an open formal meeting. Even so, such asides still allow for the realization that orthodoxy is not all that popular or slavishly followed and younger therapists in particular may soon realize the illusory nature of 'standard practice." Id. at 361 .
} 
orient his therapy towards eliciting behavior which will place the patient in legal jeopardy. ${ }^{44}$ This is not simply to say that the psychiatrist himself may not violate the criminal law in his practice. It means also that, should the patient have drug addiction symptoms, ${ }^{45}$ the psychiatrist should not orient his therapy towards maintaining the use of narcotics as a condoned means of defense. ${ }^{46}$ Likewise, if the psychiatrist indulges in fornication with his patient, it is not simply that the psychiatrist is not privileged to break the criminal law, but that whatever his right to take his own fate in his hands, he is not legally protected in encouraging his patient to do so. ${ }^{47}$

Although the rules of the medical ethics may offer some threshold direction in the search for the terms of the trust, the motives of the negligent psychiatrist need not constitute a breach of ethics for liability to exist. In Landau v. Werner the court absolved Dr. Werner of any professional misconduct even though it held him

\footnotetext{
s See Rosenfeld v. Coleman, 19 Pa. D. \& C.2d 685, 85 North. Co. R. 206 (C.P. Northampton County Ct. 1959). In Rosenfeld, plaintiff became defendant's patient after suffering migraine headaches, nervousness, and general weakness. When plaintiff complained of severe pains a month later, defendant provided plaintiff with a pre. scription for demerol, a synthetic narcotic drug. Upon plaintiff's return from the pharmacy, defendant instructed him in the use of, and provided him with a syringe for injection of the drug. After some counseling psychiatric treatment ceased, but the prescriptions for demerol were continued. Plaintiff was eventually diagnosed by the Pennsylvania Department of Health as an addict. The addiction, it was al. leged, began under defendant's care. The court held it error to enter a nonsuit since one purpose of the Anti-Narcotics act was to limit prescriptions for drug addicts. Id. at $643,646,35$ North. Co. $R$. at $212,214-15$. While the case is initially concerned with measuring the psychiatrist's liability under the criminal statute, tbe facts include and suggest limits where, as there, the patient is led to a path of behavior which subjects him to the sanctions of the criminal law.

so Rosenfeld v. Coleman, supra note 44.

"See Menninger, A Psychiatric View of the Police, The Police Chief, Dec. 1956, p. 41. "We psychiatrists have not made it sufficiently clear that attempting to understand an individual whom we treat is not necessarily to condone all the behavior of such an individual or even to expect inevitable penalties for such behavior to be waived merely because he is in treatment. Not all my colleagnes agree with me about this. But I think we psychiatrists have sometimes put ourselves in a bad light by giving the impression that if a man is taking treatment, he should be permitted continued offensiveness without penalty. I am willing to try to help him with his temp. tations; but not with his crime. I am willing to try to help a man who is tempted to commit murder or arson, but $I$ am not willing to treat a man-as an outpatientwho can't resist doing so. I grant that homosexual seductions, ctc. are less serious than arson or murder, but the principle is the same." Id. at 44.

17 Kleptomania may be a more universal example because sexual mores in transition have created a sexual law with mixed adherence. See Sachnoff, Book Review, 13 Archives General Psychiatry 478, 479 (1965).
} 
liable for malpractice. ${ }^{48}$ The standard of the law of negligence is an objective one.

\section{The psychiatrist's interest and the countertransference}

Aside from the variety of conscious interests which he may pursue, the psychiatrist may have some duty to control his own emotional needs, conscious as well as unconscious. ${ }^{49}$ To be sure, he may pursue interests of his own: surely his financial interest in being compensated, his professional interest in achieving a successful treatment, and his own emotional welfare are not to be completely denied. Undoubtedly, he must maintain his emotional stability if only because without it his capacity to empathize and participate in the therapy by infusing it with his own energy might be lost. However, the interest must be followed only to the extent that it does not conflict with, but rather tends to serve, the patient's emotional well-being. If the psychiatrist hurts himself emotionally, he might imperil the patient's stability.

On the other hand, if allowances were not made for the possible psychological involvement of the psychiatrist, perhaps only an emotionally flat analyst with no emotional needs of his own would be legally protected against a malpractice action. The law does not appear to require that a psychiatrist who seeks to defend against a malpractice action have been successfully analyzed. ${ }^{50}$ His every action need not be drive reduced and free of neurotic motive, nor need it be uniformly recognized or accepted as drive reduced by the psychiatric community. If, indeed, it were required of psychiatrists that their emotional understanding be complete in the view of the psychiatric community, there might not be enough psychiatrists available for the treatment of the mentally ill. Even the psychiatric

\footnotetext{
${ }^{18}$ Whether the scope of the implied contract or representation to employ the profession's standards of skill and care extends to include its standards of comportment and deportment may be an open question. Nevertheless, Landau stands for the proposition that ethical professional conduct is not a defense to an action for malpractice. The necessity of ethical conduct recognizes an interest in privacy-something of decency and modesty-rather than a purely medical interest. However, in psychotherapy where, as the Queen's Bench witness in Landau stated, there "could be no separation between social and professional conduct," fixing the limits of proper conduct becomes difficult indeed.

"See Greenson, The Classic Psychoanalytical Approach in 2 American Handook of Psychiatry 1399, 1409, 1413 (Arieti ed. 1959); Fisch, supra note 42, at 360-61.

${ }^{\text {so } A}$ failure to have undergone analysis may be the case among psychiatric residents or interns.
} 
resident-a learner who may yet lack full understanding of his own motives-must be utilized to provide therapy. ${ }^{31}$ Psychiatry remains a scarce resource.

On the other hand, some measure of understanding of and control over the countertransference ("a transference reaction of the therapist to his patient" ${ }^{2}$ ) is prerequisite to a defense of an action in malpractice..$^{53}$ However, the extent of insight into and control over one's own motives and over the countertransference need not be complete to be legally protected. The standard of practice of the medical profession must be the guide to the case by case solution of this problem.

The failure to exercise such control in a given case, however, may be difficult to prove because of the limited external verifiability of a person's motives, so many of which may be unconscious. An example from the psychiatric treatment of suicidal patients will suffice. A psychiatrist recently pointed out ${ }^{54^{4}}$ that decisions once made in the security of a locked ward are now made on the outside, thus creating anxiety among psychiatrists.55 This anxiety may be

\footnotetext{
${ }^{5}$ See Ungerleider, That Most Difficult Year, 122 AmErican J. Psychiatry 542 (1965).
}

As far as interns are concerned, the case law does not convincingly demonstrate that they are chargeable either with the standard of care of a student or, on the other hand, with that of a licensed professional. Sce Note, 95 U. PA. L. REv. 239 (1946). In the closest treatment of the situation, the court held for the defendant, an unlicensed dental intern, since there was no expert testimony that his practice was not in accord with the standard of the profession. Haliburton v. General Hosp. Soc'y of Connecticut, 133 Conn. 61, 48 A.2d 261 (1946). But cf. Owl Drug Co. v. Crandall, 52 Ariz. 322, 80 P.2d 952 (1938); Christensen v. Des Moines Still College of Osteopathy \& Surgery, 248 Iowa 810, 82 N.W.2d 741 (1957); Carey v. Davis, 190 Iowa 720, 180 N.W. 889 (1921); Nickley v. Eisenberg, 206 Wis. 265, 239 N.W. 426 (1931).

"2 Greenson, supra note 49, at 1413. See text at note 9 supra.

"Countertransference can be roughly defined as the converse of transference: the repetition of previously acquired attitudes toward the patient, such attitudes being irrational in the given situation." Cohen, Countertransference \& Anxiety, in AN OUtLINe of Psychonnalysis 539 (1955). "When in the patient-analyst relationship, anxiety is aroused in the analyst with the effect that communication between the two is interfered with by some alteration in the analyst's behavior (verbal or otherwise), then countertransference is present." Id. at 547. (Emphasis omitted.) Such a definition thus includes "all situations where the analyst was unable to be useful to the patient because of difficulties with his own responses." Id. at 546.

${ }^{53}$ Landau v. Werner (C.A. Nov. 22, 1961) in The Times (London), Nov. 23, 1961, p. 5, col. 1.

s Address by Milton Rosenbaum, M.D., George Washington University Symposium on Suicide, October 14, 1965.

${ }^{*}$ Compare Ungerleider, supra note 51, at 543 .

For a more generalized treatment of liability in cases of suicide, sce Perr, Liability of Hospital and Psychiatrist in Suicide, 122 American J. Psychistry 631 (1965). See 
transmitted to the patient so that the patient utilizes the suicidal defense. The physician may thus be compelled to ask himself in a given case whether his concern about the possibility of suicide derives from the patient's needs, or from his own desire to be rid of the patient. In a similar vein the psychiatrist might decide to hospitalize the patient as a way of getting rid of him. Sensing this, the patient might turn to suicide. Here the doctor's own hostility toward his patient may determine the patient's action. A suicide attempt can thus be precipitated by the psychiatrist's covert attempt to be rid of the patient by sending him to a remote institution.

Understanding the legal import of these situations requires us to make a distinction between psychoanalytic interpretation and the breach of duty. It may be difficult to prove, for example, that sending a patient to a remote hospital amounts to a breach of duty. This is not only because, unlike many who bring actions for wrongful commitment, the patient is admittedly in need of psychiatric treatment. Furthermore, proof of a hostile unconscious motive on the psychiatrist's part does not necessarily amount to a breach of duty. Nevertheless, psychoanalytic interpretation has not yet been clearly excluded from the scope of permissible expert testimony, though its comprehension and acceptance by the jury cannot be guaranteed. The question in each case should be whether the doctor has taken undue advantage of the relationship for the pursuit of personal gain; whether he has demonstrated a control of his own motives which falls below the standard of the relevant psychiatric community, not alone whether his treatment was an expression of his unconscious hostility toward the patient. In deciding whether the psychiatrist should be held liable for the suicides in the examples given, the court would thus proceed on a two-step course. It would first decide whether the psychiatrist's degree of control of his own anxiety or of his hostile feelings toward the patient fall below the level of the relevant psychiatric community. It would then address itself to problems of causation.

\section{Proof of injury and proximate cause}

Even where there has been some act of negligence by the psychiatrist, perhaps most significantly where he has breached his duty

also Hirsh v. State, 8 N.Y.2d 125, 168 N.E.2d 372, 202 N.Y.S.2d 296 (1960); Collins v. State, 23 App. Div. 2d 898, 258 N.Y.S.2d 938 (1965). 
to the patient, the psychiatrist will not be held responsible for a subsequent injury which is not the proximate cause of his breach. ${ }^{50}$ In-short, the injury must be within the risk exposed by the breach, and the person who is injured must be among the group protected by the duty. Sometimes, however, patients who have begun psychotherapy, after having established a pattern of neurotic symptoms, experience psychotic episodes while in treatment. It must be understood that such incidents may be unavoidable in the course of therapeutic probing. However, what is peculiar in this situation is that a suit instituted after such an incident may fix liability upon the downside of a curve before its future path upward has had a chance to emerge. The difficulty of proving injury in such a case is, in part, due to insufficient knowledge of the course of the illness. Thus, the tendency in some instances to attribute failure of improvement to a breach of duty on the part of the psychiatrist may be a dangerous one..$^{57}$

\footnotetext{
${ }^{60}$ Eisele v. Malone, 2 App. Div. 2d 550, 157 N.Y.S.2d 155 (1957). Plaintiff alleged negligence in the psychiatrist's continued use of shock therapy after symptoms of spinal fracture appeared. The claim was made, inter alia, that the hospital was negligent in failing to provide adequate $X$-ray facilities, and it was alleged that such an examination was essential since it would have revealed the fracture and avoided further injury. It was held that the verdict was invulnerable on this issue but that the proof did not sustain the jury's conclusion that the absence of $X$-ray facilities was, as it had to be, "directly related to and causative of plaintiff's condition." There was no proof that, as the jury clearly believed, the doctor would have ordered $\mathrm{X}$-rays for plaintiff if such facilities had been available.

${ }^{57}$ See Hammer v. Rosen, 7 App. Div. 2d at 217, 181 N.Y.S.2d at 806 (1959) (dissent), modified, 7 N.Y.2d 376, 165 N.E.2d 756, 198 N.Y.S.2d 65 (1960). In the dissenting opinion in the Appellate Division (with which the Court of Appeals agreed), Judge McNally observed: "It is conceded that at the conclusion of defendant's treatment between $\mathrm{I} 948$ and 1955, involving expenditures of over $\$ 55,000$, the condition of the patient plaintiff had not improved. The lack of improvement despite the time lapse establishes regression rather than stabilization of her condition." Ibid. Implicit. in this statement is the attitude that the injury was the regression itself.

But see Landau v. Werner (C.A. Nov. 22, 1961) in The Times (London), Nov. 23, 1961 , p. 5, col. 1. Lord Justice Sellers stated the question as whether Dr. Werner was negligent, and if so, whether he caused a "further breakdown" in the health of Miss Landau. This statement nullifies any question raised elsewhere in the opinion as to the liability for return to her former condition. The question is a complicated onc. Is the psychiatrist liable only for the declines which bring the patient below the pretherapy level of his condition? There may be a point at which a gain realized in the therapy has taken residence in the patient's personality and exists there aside from a level of substantial dependence upon the psychiatrist. The difference is between a tenancy at will and a frechold held by the psychiatrist in the patient's personality or particular defense mechanism. In between are a range of levels of dependence whose identification as "substantial" must be the product of case by case evaluation. Surely the psychiatrist cannot escape the consequences of malpractice which cause a decline from ego development (dependent upon identification) to its pre-therapy level. On the other hand, the gains which depend upon close thera-
} 
Only under rare circumstances does a psychiatrist give and may therefore be held to an assurance of cure. What he engages to do ordinarily is to pursue a cure by the methods of his profession. This has been recognized by courts dealing with psychiatric treatment, ${ }^{68}$ but there has been a concomitant tendency to consider sympathetically arguments based upon the disparity between lengthy and costly treatment and failure of improvement. At some point, perhaps, there may be a duty upon a psychiatrist whose continued application has borne no visible fruit to abandon the case or to seek consultation. ${ }^{59}$ However, only in one case, and there where the patient had "fallen in love" with the doctor, was termination of treatment considered the duty of the psychiatrist. ${ }^{60}$ To the extent

peutic support may not have been won to substantial freedom from the psychiatrist so that their loss is understandable as having been wrested from the patient. So likewise are those "technical corrections" which are experiential declines from over-extended positions in the development of the personality during therapy. Thus might a depressed patient become psychotic for two hours in the process of assimilating new levels of independence and ego strength. In such cases as in cases of somewhat longer psychotic breaks which occur when emotionally laden areas are therapeutically explored, the psychiatrist ought not to be held to answer in damages.

In this connection it has been suggested that the level of pre-existing condition and the possibilities for cure determine the base line for the assessment of damages and that both involve questions for expert determination. See Bellandi v. Park Sanitarium Ass'n, 214 Cal. 472, 480-81, 6 P.2d 508, 512 (1931).

us Johnston v. Rodis, 251 F.2d 917 (D. C. Cir. 1958). "Doubtless a physician's statement that he would cure a disease could seldom if ever be regarded as a warranty. But that is not this case. The statement attributed to the defendant, that shock treatments are 'perfectly safe,' contains less of prediction and more of present fact. We think this statement, if the defendant made it and did not qualify it in any way, might properly be found to be a warranty." Id. at 918. Accord, Howe v. New York, 33 Misc. 2d 147, 153, 226 N.Y.S.2d 933, 939 (Ct. Cl. 1962) (by implication); Hammer v. Rosen, supra note 57; Landau v. Werner, supra note 57 (by implication).

${ }^{\circ}$ In Landau $v$. Werner the Court of Appeal enunciated a duty to abandon the therapy in terms that reach broadly through the concept of duty to encompass a duty of consultation. At the moment when the patient had "fallen in love" with the psychiatrist, the court demanded Dr. Werner's withdrawal: "It seemed now that the most prudent thing for Dr. Werner to have done was to refer Miss Landau back to her own doctor and advise that the treatment was not completed and should be resumed with someone else." (C.A. Nov. 22, 1961) in The Times (London), Nov. 23, 1961 , p. 5, col. 1 .

${ }^{60}$ Landau v. Werner, supra note 59. A holding which appears on its face to be contrary to Landau is Gasperini v. Manginelli, 196 Misc. 547, 92 N.Y.S.2d 575 (Sup. Ct. 1949). In that case it was held that allegations of a defendant psychiatrist's failure to consult another psychiatrist before commencing treatment did not state a cause of action for malpractice. "Defendant was himself a psychiatrist who had been called in by the family physician. It is understandable that he did not see the need for a consulting phychiatrist." $I d$. at 550,92 N.Y.S.2d at 578 . The decision is limited to the naked requirement of employing a consulting psychiatrist at the outset of therapy and would probably not govern a state of facts where long continued therapy had borne no apparent results. Uncertainty of result, of condition, or of completed treatment may raise a duty on the part of a psychiatrist to consult. 
that recognition of such a duty motivates the tendency to give mere failure of improvement the weight of injury, it ought to be made explicit in the cases. To the extent that sensitivity to the disparity between fee and result is the underlying factor, the tendency is to be criticized. Proof of maintenance of condition where decline is a real possibility presents a probable line of defense. To sustain a cause of action for malpractice there must be proof that improvement, of which there was a substantial likelihood, was prevented by the psychiatrist's breach of duty.

On the other hand, there need be no proof of the effect of a tortious act on the course of treatment itself where there is proof of independent injury from which pain and suffering flow as natural consequences. Thus, the New York Court of Appeals held in Hammer v. Rosen that since "damages recoverable in malpractice are for personal injuries, including the pain and suffering which flow from the tortious act," proof of bruises will sustain a jury's findings that acts of assault have caused plaintiff pain and suffering."

\section{The role of the courts}

The price of recognizing a cause of action for psychiatric malpractice is some judicial ordering of psychiatric behavior. At times this can be quite problematic. In the view of the Court of Appeal in Landau v. Werner, for example, the course which Dr. Werner should have taken upon discovering that his patient had fallen in love with him was to abandon the therapy. It is settled, however, that the evocation of feelings such as those which Miss Landau experienced is not the signal for termination of the relationship. On the contrary, such intensity of feeling is not only the mark of some therapeutic success, but the prelude to insight on the part of the patient. Such a resurrection of the repressed feelings of childhood allows the intellectual and emotional examination of feelings not previously understood or dealt with. Through such re-examination the emotional learning of psychotherapy occurs. ${ }^{62}$ Uncertain of the effects of this process, ${ }^{03}$ the court could not accept Dr.

61 7 N.Y.2d at 378,165 N.E.2d at 758,198 N.Y.S.2d at $67-68$.

62 See Witenberg, Rioch, \& Mazer, The Interpersonal \& Cultural Approaches, in 2 Amserican Handbook of Psychiatry 1417, 1426 (Arieti ed. 1959).

63 "She was ashamed and baffled at the way her affection had developed towards a married man with two children. It was something that was perhaps inherent in the system of treatment of transference." (C.A. Nov. 22, 1961) in The Times (London), Nov. 23, 1961, p. 5, col. 1 . 
Werner's judgment that a relapse would probably accompany Miss Landau's removal from his influence. It could not visualize the social visits as his sincere attempt to find a therapeutic solution to the problem of gratifying the patient's dependency need while at the same time fostering independence. Why then was the termination of the relationship, rather than continued but less frequent therapy, the path to have been followed?

The answer may have something to do with the fact that the medical testimony before the court was taken as a uniform condemnation of social visits. Such uniformity may have been only an accident of proof. That testimony for Dr. Werner's technique may have been difficult to obtain is not only witness to the reluctance of physicians generally to testify in malpractice cases, ${ }^{64}$ but is a special problem in the proof of the standard of practice in the relevant psychiatric community.

Although not explicitly in response to these facts, courts have not required expert testimony to establish that behavior "whose very nature bespeaks improper treatment and malpractice" is wrongful. In Hammer $v$. Rosen the Court of Appeals held that it was error not to submit the issue of malpractice to the jury even though there had been no expert testimony to the fact. The testimony of three witnesses that the defendant had beaten his patient on a number of occasions made out a prima facie case. ${ }^{65}$ This rule has been elsewhere recognized in cases of psychiatric malpractice where severe assaults have resulted in physical injury to the patient. ${ }^{66}$ Following it in cases of emotional injury might create more of a problem. In either case, expert testimony can rebut the prima facie case. To the extent that the court's answer in Landau v. Werner reflects uneasiness in handling psychiatric doctrine, repeated dealings with psychiatric malpractice situations may dispel some uncertainty. Routinization of psychiatric procedure may eliminate

'See Note, Malpractice and Medical Testimony, 77 HARv. L. REv. 333 (1963).

¿s See note 37 supra.

oo Bellandi v. Park Sanitarium Ass'n, 214 Cal. 472, 6 P.2d 508 (1931) (death by choking employed to restrain patient); Burton v. Leftwich, 123 So.2d 766 (La. Ct. App. 1960) (assault and battery upon child patient employed to keep her still while removing sutures); Note, 77 HARv. L. REv. 333, $346 \mathrm{n.81}$ (1963). The doctrine of res ipsa loquitur is sometimes applied in this context. See Sawyer v. Jewish Chronic Disease Hosp., 234 N.Y.S.2d 372, 374 (Sup. Ct. 1962).

Hammer $v$. Rosen should not be read to condemn all physical restraint, whether by straps or hand, when it is necessary to control the patient. See generally Annot., 89 A.L.R.2d 983 (1963). 
the rest. Nevertheless, the extent of sometimes covert innovation within the psychiatric community suggests that procedures such as those of Drs. Rosen and Werner may persist. ${ }^{67}$

\section{Conclusion}

Through unfamiliarity with mental illness and psychiatry and because of problems in the nature and development of psychiatry itself, the few cases in which courts have considered psychiatric malpractice provide only limited and sometimes confusing guidelines to the medical profession. Continued litigation may provide more clarity. Some aspects of malpractice as they have emerged in the decided cases between psychiatrist and patient have been considered. It has been suggested that because the concept of trust plays so large a part in psychotherapy-and as a tool of legal analysis admits the concept of preferential interest-it should be explored as a guide to deciding cases of malpractice concerning the therapeutic relationship. The medical profession itself can provide standards for judging the patient's interest in a given case. Countertransference might then be regulated, and the limits of psychiatric activity delineated by requiring the psychiatrist continually to prefer the interest of his patient to his own.

\footnotetext{
${ }^{67}$ Compare Fisch, supra note 42 , at 362.
} 